\title{
Aktualisasi Pendidikan Karakter Melalui Pembelajaran Sejarah
}

\author{
DESVIAN BANDARSYAH \\ FKIP UHAMKA
}

\begin{abstract}
Abstrak
Berbagai persoalan serius dan sistemik mengenai kebangkrutan moral, hilangnya rasa tanggungjawab, dan disorientasi kebangsaan yang bersifat multidimensional, terjadi tidak hanya pada level kepemimpinan nasional, tetapi juga pada level lokal, bahkan sampai tingkat generasi mudanya. Hal itu mendorong perlunya pendidikan yang dapat menjawab berbagai perubahan sosial di tengah-tengah perkembangan masyarakat yang menglobal. Persoalan mendasar berkaitan dengan peranan pendidikan adalah bagaimana pendidikan dilakukan dengan memuat nilai-nilai humanis serta membentuk karakter dan perilaku yang sesuai dengan perkembangan dalam dunia yang terus berubah dari waktu ke waktu. Kita harus mampu menyelenggarakan pendidikan yang mengacu ke masa depan. Pendidikan yang mempersiapkan generasi muda untuk menatap masa depan yang lebih baik, dengan pemaknaan terhadap kehidupan yang dinamis secara positif yang berkaitan dengan upaya pengembangan kualitas dan kemandirian manusia Indonesia. Sehingga dimungkinkan secara proaktif dapat menjawab tantangan masyarakat dan bangsa, dalam dunia yang kompleks. Dunia keilmuan dan corak pendekatan pendidikan kita dalam tataran teoretis dan praktis harus mampu melepaskan diri dari pengaruh kelimuan warisan Cartesian yang mekanistik positivistik. Desain ilmu-ilmu sosial dalam pendidikan, terutama pendidikan sejarah harus dapat menawarkan kemandirian, melalui pengembangan karakter, kesadaran dan nalar kritis dengan memfungsikan kesadaran etis dan estetika. Ilmu-ilmu sosial dan sejarah merupakan solusi dalam mengatasi krisis kemanusiaan dewasa ini. Terutama pembelajaran sejarah dengan implementasi yang tepat.
\end{abstract}

Kata Kunci: ilmu sosial, pendidikan karakter, pembelajaran sejarah

\section{Abstract}

Serious and systemic problems regarding moral bankruptcy, losing sense of responsibility, and multidimensional disorientation nationality occur not only at the national leadership level but also at the local level, even to the level of the younger generation. This encourages to provide education that can address a variety of social change in the midst of the global as well the development of society. A ffundamental issue related to the role of education is how education is performed by accomodating humanist values as well as develop character and behavior in accordance with the developments in the world that keeps changing from time to time. We must be capable of implementing education that refers to the future. Education that prepares young generation to face the better future by defining the dynamic life positively associated with the quality and autonomy development of Indonesian human. Thus, it is possible to proactively address challenges of society and the nation in a complex world. The world of science and style of our educational approach in a theoretical and practical level should be able to escape from the influence of Cartesian mechanistic positivistic heritage. Design of the social sciences in education, especially history education should be able to offer autonomy through character development, awareness and critical reasoning by functioning ethical and aesthetic consciousness. Social sciences and history is a solution to overcome the humanitarian crisis today especially the teaching of history with proper implementation.

Keywords: social sciences, character education, the teaching of history 


\section{PENDAHULUAN}

Beberapa waktu terakhir dunia intelektual kita dan masyarakat kita pada umumnya, di warnai dengan pemberitaan hangat mengenai persoalan kemunduran moralitas, sistem nilai, kejujuran, tanggungjawab, dan nilai-nilai lainnya yang berlaku dan dilakukan dalam masyarakat kita. Kita terkesan kaget, gugup dan tidak siap dengan situasi yang berkembang itu. Ini tercermin dari perdebatan yang berlangsung mengenai hal itu. Padahal kondisi yang diperdebatkan itu sudah berjalan cukup lama, bahkan mungkin sejak tahun 1980-an, sebagai dampak dari pembangunan nasional kita di masa lalu yang lebih diorientasikan kepada persoalan pragmatis-ekonomis, ketimbang persoalan ideologis-politis sebagai bagian dari upaya pembangunan karakter bangsa (nation and character building).

Maka tidak mengherankan jika pada hari ini, bangsa ini menuai persoalan yang cukup serius, akut, sistematis, dan sistemik mengenai kebangkrutan moral, kemerosotan ahlak, rasa tanggungjawab, dan disorientasi kebangsaan yang bersifat multidimensional, tidak hanya pada level kepemimpinan nasional, tetapi juga pada level lokal, dan bahkan sampai tingkat generasi mudanya.

Hal itu mendorong perlu diadakannya pendidikan yang dapat menjawab berbagai perubahan sosial di tengah-tengah perkembangan masyarakat yang menglobal. Persoalan mendasar berkaitan dengan peranan pendidikan adalah bagaimana kita mengadakan pendidikan yang dapat memuat nilainilai humanis serta membentuk karakter dan perilaku yang sesuai dengan perkembangan dalam dunia yang terus berubah dari waktu ke waktu.

Berkaitan dengan hal itu diperlukan gambaran yang jelas tentang masyarakat yang dikehendaki juga jenis pendidikan yang diinginkan. Perspektif yang demikian diperlukan dalam mengembangkan pendidikan bagi generasi muda dan pembangunan bangsa. Sebagai sebuah proses, pendidikan dirancang untuk mewariskan nilai dan budaya dalam masyarakat dari satu generasi ke generasi lainnya, yang diharapkan mampu mengha- silkan manusia Indonesia yang demokratis, kreatif, dan mandiri, yang mampu berperan sebagai pembangun bangsa. Singkatnya manusia yang baik dan berguna bagi bangsanya.

Dengan demikian kita harus mampu menyelenggarakan pendidikan yang bersifat antisipatoris dan prepatoris (Buchori, 2001), yaitu jenis pendidikan yang mengacu ke masa depan dan mempersiapkan generasi muda untuk menatap masa depan yang lebih baik, dengan pemaknaan terhadap kehidupan yang dinamis secara positif yang juga dikaitkan dengan upaya pengembangan kualitas dan kemandirian manusia Indonesia yang memungkinkan mampu dan proaktif menjawab tantangan masyarakat, bangsa, dalam dunia yang kompleks.

Pendidikan semacam itu merupakan persoalan dan tuntutan yang tengah dihadapi bangsa Indonesia, sejalan dengan semakin merosotnya kualitas kehidupan manusia dari sisi sosial humanitasnya. Tentunya persoalan di atas perlu dicarikan solusi melalui refleksi dan perenungan yang mendalam mengenai akar persoalan dan solusi apa yang dapat ditawarkan. Makalah ini berupaya untuk memberikan jawaban atas persoalan tersebut, sehingga pendidikan dapat berkiprah dalam menjernihkan pencapaian arah tujuan pendidikan nasional kita untuk menjadi baik.

\section{Pendidikan dalam Kerangkeng Hegemoni Cartesian dan Newtonian}

Perkembangan peradaban manusia di era modern yang serba canggih dan menakjubkan yang ditandai dengan kemajuan ilmu pengetahuan dan teknologi, tidak dapat dipungkiri merupakan dampak yang ditimbulkan dari bekerjanya sistem pengetahuan yang dibangun sejak abad pencerahan, dengan salah satu tokoh sentralnya Rene Descartes, seorang filsuf Prancis yang mengedepankan konsep "Cogito, ergo sum", aku berpikir, maka aku ada. Sebuah konsep berpikir yang diawali dengan meragukan semua yang ada disekitar dirinya, termasuk dirinya sendiri, yang akhirnya mengarah pada hakikat objektifitas yang nyata dari yang berpikir, maka bersifat positif, sehingga segala sesuatu yang benar harus nyata dan bersifat positif. Inilah dasar 
dari gagasan positivisme yang mempengaruhi dunia ilmu pengetahuan dengan segala turunannya selama kurun dua abad terakhir.

Konsepsi filosopinya berangkat dari pola berpikir matematis, karena ia seorang ahli matematika, ia mengatakan dalam konteks itu: "saya mengakui, tidak menerima apapun sebagai kebenaran jika tidak dapat direduksi, dengan kejelasan gambaran matematika, dari pengertian-pengertian umum yang kebenarannya tidak dapat kita ragukan lagi" (Capra, 1998: 62). Maka tidak mengherankan kalau dalam konsep filsafat ilmu, bahwa sarana berpikir ilmiah yang mencakup tiga bagian, dua diantaranya merujuk pada pandangan ini, yaitu matematika dan statistika, di samping bahasa, sangat kental mendominasi pola berpikir ilmiah secara efistemologi keilmuan.

Dalam konteks itu, baik ilmu alam maupun ilmu sosial berkembang ke arah mekanisasi ilmu yang bersifat rigid mekanistikpositivistik, yang menempatkan ilmu tidak lagi ditujukan untuk kemanusiaan yang mensejahterakan, tetapi ilmu ditujukan bagi perkembangan ilmu dan teknologi semata. Dengan kata lain, di abad modern ini, ilmu mengabdi untuk industri. Maka tidak mengherankan, kita menyaksikan betapa kehidupan semakin keras dirasakan oleh manusia yang hidup di dunia ini. Ruang kehidupan menjadi semakin kompetitif, brutal, kejam dan tanpa kemanusiaan.

Modernitas dengan segala pencapaian peradabannya, telah meninggalkan "lubang hitam" berupa problema kemanusiaan abad ini bagi kehidupan manusia modern. Cara hidup yang dimunculkan oleh modernitas menurut Giddens (1990: 4) telah mencabut manusia dari jenis tatanan sosial yang tradisional dengan cara yang tidak pernah ada sebelumnya. Dalam arti eksistensionalitas dan intensionalitasnya, transformasi yang berlangsung dalam modernitas lebih menonjol dibandingkan dengan perubahan yang terjadi pada periode sebelumnya. Kemajuan teknologi dan informasi membuat dunia mengalami "culture shock", diakibatkan karakter kehidupan sosial modern yang cepat berubah telah menimbulkan keguncangan hebat bagi penghuninya.
Proses modernitas semacam itu, menuntut adanya keseimbangan baru yang menuju pada harmoni, yang hingga sampai saat ini belum dapat terpenuhi oleh perkembangan global. Modernitas yang ditopang oleh proses perkembangan sains telah menimbulkan mitos, bahwa hanya sains dan metode ilmiah saja yang dapat menjelaskan dengan memuaskan segala fenomena alam dan sosial yang berlangsung di hadapan kita (Wiriaatmadja, 2002: 292-293). Alih-alih berupaya menjelaskan berbagai fenomena alam dan sosial, ternyata dunia sains dan metode ilmiah dengan pendekatan Cartesian gagal dalam menterjemahkan fenomena alam dan sosial yang dihadapi manusia di abad modern ini.

Dalam perspektif ini, humanisme mengalami krisis karena teknologi telah menjalankan kontrol terhadap pemindahan gagasangagasan budaya humanistis demi peragaan subjek manusia berdasarkan pada ilmu-ilmu pengetahuan dan kemampuan produktif yang dikontrol secara rasionalistik dan sekularistik. Penjelasan Vattimo (2003: 98) yang dilandasi oleh corak pemikiran nihilisme Nietzsche berikut ini menguatkan argumentasi rasionalistik sekularistik dimaksud:

“...Kita juga bisa mengakui hipotesis bahwa humanisme berada dalam krisis karena Tuhan telah mati: artinya substansi krisis humanisme yang sesungguhnya adalah (tambahan penulis: karena) kematian Tuhan. ... Karena alasan ini maka kematian Tuhan, yang sekaligus merupakan puncak dan kesimpulan metafisika, juga adalah krisis humanisme..."

Dalam kaitan itu, ruang privat telah "terdeinstitusionalisasikan" sebagai akibat dari dominasi organisasi birokrasi berskala besar dan pengaruh umum "masyarakat massa". Ruang bagi kehidupan publik, pada sisi lain, telah mengalami "over institusionalisasi". Sebagai konsekwensinya, kehidupan pribadi menjadi sirna dan tanpa titik acuan yang tegas (Giddens, 1990: 115). Konteks ini mendorong manusia untuk memasuki kehidupan publik yang didominasi kesadaran massa dengan mengesampingkan kesadaran personal sebagai individu, yang sesungguhnya 
merupakan kesadaran orisinal yang dimilikinya. Maka manusia modern kehilangan kesadaran personal dan hanyut dalam kehidupan dunia materi, sementara itu sebagai konsekwensinya, ia kehilangan nilai-nilai humanis sebagai manusia. Itulah kebanyakan manusia di era modernitas.

Namun demikian, selama proses kemunduran yang menyakitkan itu, kreativitas masyarakat dalam upaya menanggulangi tantangan itu tidak hilang sama sekali. Meskipun arus budaya telah menjadi beku dengan mengikuti pemikiran-pemikiran mapan dan pola-pola perilaku yang kaku, minoritas yang kreatif akan muncul dalam menghadapi tantangan dimaksud. Proses evolusi budaya ini akan terus berlanjut (Capra, 1997: 15). Sebuah optimisme yang diusung dalam melihat keberadaan pendidikan. Pendidikan harus dapat membangkitkan kembali sesuatu yang hilang dalam arus deras peradaban kehidupan dalam kontrol Cartesian, melalui gagasan pendidikan yang berkarakter, humanis dan kritis yang merefleksikan nilai-nilai humanistik sebagai dasar pembentukan karakter dari kodrat manusia.

Keprihatinan terhadap kerusakan lingkungan yang semakin meluas juga menjadi bagian yang tak terpisahkan dari persoalan modernitas, dan telah menjadi fokus perhatian pemerintahan di seluruh dunia. Bukan hanya dampak eksternal, tetapi juga logika kebebasan perkembangan teknologi dan perkembangan ilmiah akan saling bertentangan jika bahaya serius dan tak tertahankan tak dapat dihindari. Humanisasi teknologi tampaknya telah menyebabkan semakin meningkatnya isu moral dalam relasi yang kini "sangat instrumental" antara manusia dengan lingkungan (Giddens, 1990: 170). Dengan demikian, kesadaran semacam ini perlu mendorong pendidikan kita untuk lebih memperhatikan, bukan saja persoalan humanisasi terhadap teknologi dan ilmuilmu kealaman, tetapi juga perlu mendorong proses humanisasi terhadap ilmu-ilmu sosial dan sejarah, dengan berlandaskan pada kesadaran sikap bahwa pendidikan untuk menjadikan manusia Indonesia yang cerdas, terampil, berakhlak mulia dan berbudi pekerti, singkatnya menjadi manusia yang "sempurna".

Dalam konteks ke-Indonesiaan, kita melihat bagaimana kehidupan kita semakin sempit, landasan kehidupan berbangsa berupa hukum, ekonomi, politik, budaya sumber daya alam kita, dan bahkan pendidikan, tidak ditujukan untuk kemanusiaan lagi. Tetapi ditujukan untuk industri dan konsumsi yang semakin menggalakkan syahwat kemanusiaan kita.

Pendidikan kita pada hari ini secara kasat mata telah dirasuki oleh mekanisme pasar, mengabdi pada dunia industri. Tujuan pendidikan yang ideal, sebagaimana yang tertuang dalam cita-cita dan konstitusi kita "mencerdaskan kehidupan bangsa, mewujudkan manusia Indonesia yang berakhlak mulia, cerdas, berbudi pekerti untuk menjadi insan paripurna" semakin menjauh untuk dicapai rasanya. Hegemoni keilmuan warisan Cartesian dalam dunia pendidikan nampak dari impelementasi kebijakan Ujian Nasional yang mereduksi pendidikan sekedar berorientasi pada hasil berupa angka minimal 5,5. Inilah langgam mekanistik-postivistik ala Cartesian yang diadopsi oleh kita dalam mengelola pendidikan. Jika tidak ada terobosan yang mendasar dalam mengelola pendidikan dengan konsep filosopis dan paradigma baru yang manusiawi, maka cita-cita pendidikan nasional semakin sulit untuk diwujudkan.

Itulah misi dan tantangan utama dari pendidikan kita. Namun demikian, untk mencapai misi itu, pendidikan kita perlu ditarik keluar dari kerangkeng hegemoni Cartesian. Desain ilmu-ilmu sosial dalam pendidikan, terutama pendidikan sejarah agar lebih menawarkan kemandirian, melalui pengembangan karakter, kesadaran dan nalar kritisnya dengan memfungsikan kesadaran etis dan estetika yang dimilikinya. Nalar kritis kita dalam menganalisis sejarah akan memberikan perspektif keilmuan sekaligus juga pemahaman etis terhadap kehidupan sosial kita. 


\section{Pembelajaran Sejarah sebagai Pendidi- kan Karakter}

Asumsi keilmuan yang berkembang sebagaimana uraian di atas bukan tanpa tandingan. Dalam konteks sejarah, Wilhem Dilthey berupaya melakukan koreksi terhadap persoalan efistemologi keilmuan yang dikembangkan melalui pendekatan Cartesian. Ia berupaya meletakkan dasar epistemologis bagi ilmu kemanusiaan, terutama ilmu sejarah, dengan menempatkan kajian sejarah menjadi sejajar dengan penelitian ilmiah dalam bidang ilmu alam. Perbedaan objek kedua ilmu ini cukup mencolok. Bila ilmu kemanusiaan mengenal dua dimensi eksterior dan interior bagi objeknya artinya ia menengok realitas yang ada di luar dirinya dan di dalam dirinya, maka ilmu alam hanya mengenal dimensi eksterior yang berada di luar dirinya.

Dilthey menginginkan kritik sejarah terhadap akal menjadi kritik akal terhadap sejarah. Yang pertama berkaitan dengan kritiknya terhadap perkembangan sejarah ilmu pengetahuan yang cenderung melakukan proses generalisasi terhadap ilmu-ilmu kealaman (Naturwissenschaften) dan ilmuilmu kemanusiaan (Geisteswissenschaften). Sedangkan yang kedua, ini berkaitan dengan persoalan hermeneutika, bagaimana sejarah dikritik untuk menemukan makna di dalam sejarah sebagai jalan untuk memahami secara lebih mendalam realitas diri di tengah realitas kehidupan, daripada sekedar meneliti sejarah (Sumaryono, 1998: 46). Baginya, konsep ilmu kealaman dan ilmu kemanusiaan memiliki perbedaan yang mendasar, terutama dalam persoalan efistemologi keilmuannya. Jika ilmu-ilmu kealaman objek dan gejala-gejala yang ditimbulkannya bersifat jelas dan kongkret serta mengikuti hukumhukum alam yang universal, maka ilmu-ilmu kemanusiaan objeknya bersifat abstrak dan hukum-hukumnya partikular. Inilah yang menyebabkan cara analisis kerja keilmuan dari keduanya juga berbeda. Cara kerja Ilmu-ilmu kealaman bersifat menjelaskan, karena fenomenanya bersifat kongkret, maka diperlukan penjelasan (eksplanasi) terhadap berbagai fenomena yang ada. Sedangkan ilmu-ilmu kemanusiaan cara kerjanya bersifat memahami (interpretasi) karena objek yang menjadi kajian ilmunya bersifat abstrak. Dilthey merasakan ancaman saintisme yang begitu meluas. Ia menyadari bahwa ada bidang-bidang yang tidak bisa disentuh dengan metode ilmu kealaman yaitu kekayaan pengalaman yang bergelora dan dinamis dalam kehidupan. Ini merupakan sumbangan terbesar Dilthey di dalam menjernihkan perdebatan keilmuan di antara keduanya, tetapi juga sekaligus menjadikan persoalan keilmuan memasuki perdebatan panjang pada tataran efistemologi keilmuan.

Dilthey menganjurkan penggunaan hermeneutika, karena merupakan dasar dari ilmu-ilmu kemanusiaan, yang berkenaan dengan keterlibatan individu dalam kehidupan masyarakat yang hendak dipahaminya, maka diperlukan bentuk pemahaman yang khusus (Sumaryono, 1998: 49; Ankersmit,1987: 160; Poespoprodjo, 1987: 54). Di sini relevansi hermeneutika dalam konsep Dilthey menjadi penting untuk mengungkapkan makna dari peristiwa sejarah. model pembelajaran sejarah yang mengedepankan pendekatan hermeneutika dengan mengajukan konsep-konsep kesejarahan sebagai dasar pijakan berpikir dalam menganalisis informasi kesejarahan.

Sejarah termasuk kelompok ilmu yang lamban di dalam merespon perubahan. Padahal sikap optimisme terhadap sejarah sebagai sebuah disiplin yang menjanjikan pembentukan karakter individu akan nilai-nilai spiritual, dan kultural karena kajiannya yang bersifat memberikan pedoman terhadap keseimbangan hidup, harmoni, nilai-nilai, dan keteladanan dalam keberhasilan dan kegagalan, dan cerminan bagi pengalaman kolektif yang dapat menjadi petunjuk bagi kehidupan masa depan (Wiriaatmadja, 2002: 294). Kesadaran sejarah dapat mengendalikan kecenderungan keserakahan yang "menggurita" dari kemajuan teknologi dan industri yang mengeksploitasi hutan, sungai, udara, lautan, daratan tempat di mana manusia tinggal. Kesadaran sejarah dalam konteks ini, menunjukkan bahwa ketidakarifan dalam pemanfatan kekayaan alam dan budi akal manusia pada gilirannya akan menghancur- 
kan eksistensi kemanusiaan dan peradabannya sendiri.

Dalam perspektif pembelajaran sejarah, hermeneutika menjadi bagian yang penting untuk diterapkan. Mengingat bahwa pembelajaran sejarah sarat dengan nilai-nilai sosial kemasyarakatan, memerlukan penafsiran dalam mempelajarinya. Perspektif sejarah terikat dengan konteksnya, maka penafsiran terhadap perspektif kesejarahan dalam pembelajaran sejarah memerlukan pendekatan hermeneutika sehingga dosen dan mahasiswa dapat memahami dengan baik antara teks kesejarahan dengan konteks (realitas sosial) di mana mereka berada di dalamnya, di sini sesungguhnya proses pendidikan karakter berlangsung dengan sendirinya.

Dengan demikian bagian terpentingnya adalah bukan semata bagaimana mahasiswa belajar dari sejarah yang sarat makna, tetapi juga bagaimana mahasiswa mempelajari sejarah dengan cara bermakna. Bagian pertama akan mengisi jiwa dan membangun mentalitas kemanusiaan dan karakter mahasiswa dengan sikap arif dan bijaksana, sebagai bagian utama dari kesadaran sejarah, sedangkan bagian kedua akan membawa mahasiswa pada pengetahuan dan kesadaran bagaimana mengisi jiwa dan membangun mentalitas kemanusiaan dengan sikap arif dan bijaksana melalui pembelajaran sejarah.

Dalam kaitan itu "Community of peers" sebagai wadah yang setara dan dialogis bagi dialog antara dosen dan mahasiswa disatu pihak (Abdullah, 1991: 56; Freire, 1999: 187199), dengan informasi sejarah dan realitas sosial di pihak lain dapat "bekerja sama" dalam proses pengembaraan keilmuan bersama, sehingga mencapai suatu kebenaran ilmu pengetahuan. Penekanan yang diberikan Freire mengenai pendidikan kemanusiaan haruslah menempatkannya pada ruang kebebasan antara dosen dengan mahasiswa. Hal ini sejalan dengan konsep pengajaran sejarah yang diuraikan oleh Taufik Abdullah yang pada intinya perlu adanya "kebebasan" dalam kesetaraan dalam pembelajaran sejarah. Dalam konteks ini, pemberlakukan terhadap pengetahuan menjadi berubah, dari tingkatan doktrin ke arah tingkatan ilmu.
Dialog semacam itu menjadi relevan dalam memperluas horizon cakrawala pemikiran mahasiswa. Mahasiswa berdialog bukan tanpa pemahaman sama sekali. Dalam situasi seperti itu kita menyadari bahwa sudut pandang kita bukanlah satu-satunya cara. Dengan melihat adanya sudut pandang lain, maka kita akan melihat dengan jelas cara pandang atau pemahaman kita sendiri. Dialog yang perlukan adalah dialog untuk mengerti sesama kita dan saling belajar dari pandangan masing-masing. Karena dengan dialog kita akan mencapai pemahaman.

Dialog kebebasan dalam kesetaraan menuntun mahasiswa untuk menemukan hidup dan kehidupan yang bermakna. Pergaulan intelektual di kalangan mahasiswa hanya akan dinamis dan membuahkan hasil kebudayaan yang memperkaya wawasan intelektualnya apabila berlangsung secara dialogis. Pengertian dialogis di sini bukan sekedar adanya dua pihak yang terlibat dalam diskusi, melainkan merupakan pertemuan lebih dari satu wawasan dari pihak-pihak yang bisa bersepakat pada beberapa hal sebagai pijakan bersama untuk melangsungkan diskusi, meskipun dalam beberapa hal lainnya mereka dapat saling bertentangan, dan terdapat minat untuk saling mendengar dan memahami tanpa harus saling menyetujui (Heryanto, 1999: 5). Dalam iklim akademik seperti itu, di mana setiap individu, baik dosen maupun mahasiswa memiliki kebebasan, maka proses pembelajaran sejarah dapat berjalan dengan baik, sehingga pada gilirannya mencapai hasil yang baik pula sesuai dengan harapan.

Sejalan dengan itu, pembelajaran sejarah tidak semata terletak pada pewarisan nilai dalam formulasi struktural, melainkan juga dengan meletakkannya pada tujuan membangun dan mengembangkan kesadaran mahasiswa sebagai anak bangsa sesuai dengan konteks zamannya. Nilai-nilai kemanusiaan dan kesadaran atas nilai itu, merupakan penghubung sejarah sebagai nilai universal yang melampaui batasan sejarah. Formulasi tekstualnya bisa tetap tidak berubah, tetapi makna fungsionalnya harus dikembangkan sesuai dengan perkembangan 
dan tuntutan yang dihadapi mahasiswa (Mulkhan, 1996: 23-24). Sebab hal itu akan membawa mahasiswa lebih mengenali serta memahami pluralitas dan dinamika yang ada dalam masyarakat Indonesia, sehingga upaya pengenalan dan pemahaman mahasiswa terhadap bangsanya menjadi lebih terefleksikan dengan baik.

Pembelajaran sejarah membantu mahasiswa untuk memiliki corak berpikir kesejarahan, yaitu corak berpikir yang menuntut nalar berpikir kritis dengan pemahaman mendalam terhadap sejarah yang selalu memiliki dimensi kekinian dan kedepanan. Bagian terpenting dari gagasan di atas adalah menempatkan mahasiswa sebagai individu yang berdaulat, individu yang bereaksi berdasarkan intelegensi jasmaniah dan insting vital yang melalui penguasaan diri, mereka sanggup menghindar dari kekuatan hegemoni masyarakat, serta mampu melawan berbagai kekacauan sosial, chaovinisme, kekerasan (Ritzer, 2008: 42-43). Dengan demikian mahasiswa memerlukan mentalitas merdeka yang tidak terhegemoni oleh berbagai kondisi sosial yang melingkupi dirinya. Meskipun juga ia perlu memahami kondisi sosial dimaksud sebagai realitas yang dapat menopang corak berpikir kritis dalam memaknai tradisi dalam sejarah dan masyarakatnya.

Dalam upaya memaknai tradisi masa lalu, mahasiswa akan memahami dengan wawasan kekinian. Di sini jarak dengan masa lalu tidak diatasi dengan hanya mengkonstruksi kembali makna masa lalu tetapi memahaminya dengan horizon kekinian. Dalam dialog tersebut terjadi benturan antara cakrawala pemikiran mahasiswa dengan prasangka orang lain, namun kadangkala cakrawala pemikiran mahasiswa harus disimpan untuk mencoba melihat pandangan orang lain, agar mahasiswa dapat memahaminya. Sambil mahasiswa juga bersikap kritis terhadap prasangka dan tradisinya, apakah prasangka mahasiswa mengarahkannya untuk dapat mengerti atau prasangka itu justru telah menyembunyikannya dari pengertian (Mandalika, 2007). Itulah sikap kritis dimaksud, yang mendorong muncul dan berkembangnya kemampuan berpikir kesejarahan dalam pendekatan hermeneutika.

Berpikir kesejarahan menekankan aspek makna yang muncul dari realitas historis. Kehidupan membuka dan membentuk dirinya di dalam kesatuan-kesatuan yang masuk akal, dan di dalam pengertian individual kesatuan-kesatuan ini dipahami. Dalam kaitan itu, maka pengetahuan sejarah yang dimiliki oleh individu yang memahami akan membentuk karakter dirinya kediriannya. Hal ini mengandung makna bahwa seseorang dapat mengatasi fakta bahwa pengkaji sejarah terikat dengan waktu dan tempat, yang merupakan klaim kesadaran sejarah (historical consciousness), yaitu menggunakan sudut pandang sejarah pada setiap realitas yang dihadapinya. Hal ini merupakan pencapaian tertinggi di dalam mengembangkan "kepekaan sejarah" untuk melampaui kesadaran sejarah (Gadamer, 2004: 275).

Dengan demikian hal penting bagi mahasiswa, bahwa kesadaran sejarah tidak berhenti pada persoalan tekstual masa lampau sebagai pengetahuan yang dipelajari, tetapi juga bagaimana kapasitas mahasiswa berkembang di dalam memahami konteks masa lalu itu dengan mengembangkan nalar analisis terhadap konteks persoalan kekinian, sebagai pertanggungjawaban bagi kehidupan. Inilah konsepsi dari "kesadaran tentang kenisbian" suatu sense of relativity, dan mengembangkan telaah historis dengan memahami dan menghayati hubungan yang terjadi antara perkembangan sejarah sebagai ilmu dengan perkembangan masyarakat (Soejatmoko, 2010: 16-17). Kemampuan semacam ini akan menempatkan mahasiswa membebaskan diri dari belenggu substansi ilmu yang mengikat corak berpikirnya. Bahwa apa yang benar, berkemajuan, dan modern pada hari ini, ternyata menjadi usang di masa depan. Hidup bukanlah semata sesuatu sebagaimana yang dipikirkan mahasiswa, melainkan juga sebagaimana yang dihayatinya. Semakin dalam penghayatan mahasiswa terhadap dunia kehidupannya, maka semakin bermakna kehidupannya.

Dengan kesadaran sejarah, manusia berupaya menghargai kerumitan dalam mengungkap berbagai peristiwa yang meling- 
kupinya, menghargai berbagai realitas yang otonom. Kesadaran yang sama mendorong manusia untuk bersikap waspada terhadap pemikiran yang besifat sederhana, dangkal, serta menghindari kecenderungan menghadapi berbagai fenomena yang buta, yang banyak berkembang dalam kesemuan yang dangkal (Soejatmoko, 1976: 14).

Pembelajaran sejarah membutuhkan "kesadaran tingkat tinggi", dengan melibatkan swakesadaran (self awareness), suatu konsep diri yang dimiliki subjek yang berpikir dan merenung pada diri manusia, yang disebut kesadaran reflektif Capra (2009: 5152). Kesadaran reflektif melibat suatu tingkat abstraksi kognitif yang mencakup kemampuan untuk menyimpan citra-citra mental, yang memungkinkan manusia merumuskan nilai, kepercayaan, tujuan, dan strategi. Subjek yang merenung itu berdasarkan jiwanya. Hal ini sejalan dengan yang dikatakan Toynbee (2007: 26) sebagai berikut:

Jika seorang manusia kehilangan jiwanya, dia akan berhenti menjadi manusia; karena esensi manusia adalah kesadaran atas kehadiran spiritual di balik fenomena, dan jiwanyalah, bukan organisme psikosomatiknya, yang bias menghubungkan manusia dengan kehadiran spiritual ....

Dalam kaitan itu, kesadaran diri sebagai karakter "individualisme moral" merupakan produk sosial yang dilakukan atas prinsip dan refresentasi kolektif dari yang sakral. Etika individualisme yang melandaskan kebebasan manusia pada solidaritas komunal, suatu etika yang mengakui hak individu dalam hubungannya dengan keberadaan seluruh warga. Ini merupakan refresentasi pengalaman sesungguhnya dari cita-cita individualisme, dan merupakan satu-satunya jalan ke luar bagi persoalan bagaimana individu bisa tetap "punya solidaritas sementara ia semakin menjadi otonom" (Ritzer dan Godman, 2008: 110-111).

Kehidupan mahasiswa dalam masyarakatnya tidak terlepas dari komunitas budayanya yang memiliki dua dimensi: budaya dan komunal. Ide loyalitas dan kewajiban terhadap kebudayaan seseorang mengisyaratkan adanya kesetiaan terhadap jalan hidupnya, termasuk nilai, cita-cita, sistem arti dan makna, serta kepekaan moral dan spritual. Kebudayaan yang dianut setiap mahasiswa memberikan pertalian kehidupan, memberikan sumber daya bagi dunia yang masuk akal, menginspirasikan, menjadi panduan moral, dan membantu mereka mengatasi berbagai tragedi yang tidak terelakan (Parekh, 2008: 216). Semua itu menunjukkan apa yang telah dilakukan, dapat dilihat bahwa cita-cita, sistem arti dan estetika, spiritual dan pencapaian kebudayaan lainnya mewakili keseluruhan visi yang sangat berharga mengenai kehidupan manusia dan memberikan sumbangan unik bagi modal kebudayaan moral manusia.

Dalam perspektif itu, gagasan sejarah yang didorong oleh kesadaran kritis melalui proses perenungan tingkat tinggi, melahirkan corak kemampuan berpikir kesejarahan yang lahir dari pemahaman terhadap sinergi masa lalu dan masa kini. Bagi McCarthy (2008: 101) kesadaran kritis mahasiswa yang berlangsung melalui negasi terbatas, bertujuan untuk memahami konteks asal mulanya sendiri, yaitu proses pembentukan diri di mana dirinya sendiri adalah hasil dari proses tersebut. Melalui manifestasi kesadaran diri yang muncul secara silih berganti dan sistematis membentuk sejarah manusia, kesadaran sampai pada kedudukannya yang sekarang melalui tahap-tahap refleksi dengan mensinergikan nalar praktis dan nalar teoretis ke dalam bentuk kesadaran.

Kesadaran personal sebagai individualitas yang menjalankan penghayatan subjektif, sehingga mahasiswa tidak larut dan terhanyut dalam budaya massa yang dapat membuat mahasiswa terasing dari dirinya, mengalami alienasi diri, dan tidak menjalani eksistensi sejatinya. Hal ini pada akhirnya akan menghilangkan kesadarannya dan menjadi berkurang tanggungjawabnya. Pandangan eksistensialis semacam itu menjadi penting dalam mendorong proses pembentukan karakter mahasiswa, karena melahirkan dampak yang tidak hanya positif tetapi juga produktif bagi kehidupan mahasiswa sebagai individu dengan penghayatan eksistensi yang bermakna dan memiliki mawas diri. Inilah pro- 
ses pendidikan karakter dan pembentukan karakter diri yang utuh melalui belajar dari sejarah secara benar.

\section{SIMPULAN}

Problema kemanusiaan yang tengah kita dihadapi saat ini, memerlukan pemecahan sebagai jalan keluar dari dunia yang semakin sempit, brutal, dan kejam. Perlu terobosan filosopis-teoritis sebagai dasar pijakan di dalam menjalankan solusi yang tepat, terukur, sistematis, dan sistemik. Dengan demikian dunia keilmuan dan corak pendekatan pendidikan kita dalam tataran teoretis dan praktisnya harus mampu melepaskan diri dari pengaruh kelimuan warisan Cartesian yang mekanistik positivistik.

Ilmu-ilmu sosial dan sejarah merupakan solusi dalam mengatasi krisis kemanusiaan dewasa ini. Terutama sejarah melalui implementasi pembelajaran yang tepat, sejarah dapat menjadi solusi efektif terhadap berbagai persoalan kemanusiaan kita, karena sejarah memuat pesan moral kemanusiaan dan pembelajaran sejarah dapat menderegulasikan nilai-nilai moral kemanusiaan yang terdapat di dalamnya. Suatu upaya di dalam menjalankan pendidikan karakter bagi generasi masa depan. Tentu ini merupakan paparan yang tidak berlebihan... Wallahu'alam bisshawab.

\section{DAFTAR PUSTAKA}

Abdullah, Taufik. 1991. "Pengajaran dan Penelitian Sejarah: Relevance, Kebenaran Faktual, Keterangan - Peristiwa", dalam: Media Komunikasi Profesi Masyarakat Sejarawan Indonesia: Sejarah: Pemikiran, Rekontruksi, Persepsi, Jakarta: Gramedia.

Ankersmit, F.R. 1987. Refleksi Tentang Sejarah, Pendapat-pendapat Modern tentang Filsafat Sejarah. Alih Bahasa: Dick Hartoko. Jakarta: Gramedia.

Buchori, Mochtar. 2001. Pendidikan Antisipatoris. Yogyakarta: Kanisius.

Capra, Fritjof. 1997. Titik Balik Peradaban: Sains, Masyarakat dan Kebangkitan Kebudayaan. Alih Bahasa: M.Thoyibi. Yogyakarta: Bentang Budaya.

Capra, Fritjof. 2009. The Hidden Connections: Strategi Sistemik Melawan Kapitalisme Baru. Alih Bahasa: Andya Primanda.
Yogyakarta \& Bandung: Jalasutra.

Freire, Paulo.1999. Politik Pendidikan: Kebudayaan, Kekuasaan, dan Pembebasan, terjemahan: Agung Prihantoro dan Fuad Arif Fudiartanto. Yogyakarta: Pustaka Pelajar dan Research, Education, and Dialogue.

Gadamer, Hans-Georg. 2004. Kebenaran dan Metode: Pengantar Filsafat Hermeneutika. Yogyakarta: Pustaka Pelajar.

Giddens, Anthony. 1990. The Consequences of Modernity. USA: The United Kingdom by Polity Press.

Heryanto, Ariel. 1999. "Kajian Budaya Menjelang Abad 21", dalam: Akademika: Kajian Masalah Sosial Keagamaan, Rekontruksi Sosial Budaya, Muhammadiyah University Press, SurakartaNo. 02, Th. XVIII.

McCarthy, Thomas. 2008. Teori Kritis Jurgen Habermas. Alih Bahasa: Inyiak Ridwan Muzir. Yogyakarta: Kreasi Wacana.

Mulkhan, Abdul Munir. (1996). "Dialog Reflektif Nasionalisme, Agama dan Modernisasi", dalam Ariel Heryanto (pengantar), Nasionalisme Refleksi Kritis Kaum Ilmuan. Yogyakarta: Pustaka Pelajar.

Parekh, Bhikhu. 2008. Rethinking Multiculturalism: Keberagaman Budaya dan Teori Politik. Yogyakarta: Kanisius.

Poespoprodjo, W. (1987). Interpretasi. Bandung: Remadja Karya.

Ritzer, George dan Douglas J. Goodman. 2008. Teori Sosiologi: Dari Teori Sosiologi Klasik Sampai Perkembangan Muktahir Teori Sosial Postmodern. Yogyakarta: Kreasi Wacana.

Ritzer, George. 2008. Teori Sosial Postmodern. Ali Bahasa: Muhammad Taufik. Yogyakarta: Kreasi Wacana.

Soejatmoko. 2010. Menjadi Bangsa Terdidik Menurut Soejatmoko. Jakarta: KOMPAS.

Sumaryono, E. 1998. Hermeneutik: Sebuah Metode Filsafat. Yogyakarta: Kanisius.

Toynbee, Arnold. 2007. Sejarah Umat Manusia: Uraian Analisis, Kronologis, Naratif, dan Komparatif. Alih Bahasa: Agung Prihartoro, dkk. Yogyakarta: Pustaka Pelajar.

Vattimo, Gianni. 2003. The End of Modernity: Nihilisme dan Hermeneutika dalam Budaya Posmodern. Alih Bahasa: Sunarwoto Dema. Yogyakarta: Sadasiva.

Wiriaatmadja, Rochiati. 2002. Pendidikan Sejarah di Indonesia: Perspektif Lokal, Nasional, dan Global. Bandung: Historia Utama Press. 